\title{
Исторические науки
}

УДК 94(470)»18/19»

DOI: $10.14529 / \mathrm{ssh} 170301$

ББК 63.3(2)531

\section{ТЕХНИЧЕСКИЕ ИННОВАЦИИ И ЭВОЛЮЦИЯ КУЛЬТУРНОГО ЛАНДШАФТА РОССИЙСКОГО ПРОВИНЦИАЛЬНОГО ГОРОДА В КОНЦЕ XIX — НАЧАЛЕ XX ВЕКА*}

\author{
Е. В. Алексеева, Е. Ю. Казакова-Апкаримова
}

\begin{abstract}
Статья посвящена эволюции культурного ландшафта российского провинциального города в конце XIX - начале XX в. в контексте внедрения технических инноваций. Города рассматриваются как важнейшие акторы социокультурного и технического прогресса российской провинции. Потребность внедрения технических инноваций, сближающих провинциальные города со столичными, была сильнее в городах губернского значения. Авторы обращаются к истории распространения электричества в городах восточных регионов России, анализируя его многоплановое применение в быту. Исследуемая тема вписывается в мировой контекст. Авторы показывают, что российские (не только столичные, а многие провинциальные) города не так уж отставали от своих передовых европейских аналогов в плане внедрения технических новинок. Однако городской элите и городским властям провинциальных городов приходилось преодолевать значительно больше трудностей для их введения, степень распространения новинок была ограниченной по объективным причинам (не только материальным, следует учитывать и ментальные особенности провинциальных обывателей).
\end{abstract}

Ключевые слова: культурный ландшафт, города, провинция, распространение инноваций, электричество.

В современной науке активно исследуются процессы взаимодействия провинциальной и столичной культур, акцентируется внимание на диалоге общения. Провинциальная культура признается самобытной, далеко не отсталым звеном «низшего порядка». Культурологи выделяют тип провинциальной культуры, своеобразие которого проявляется в сравнении столичное - провинциальное. И. В. Отставнова, например, пишет о стереотипах противопоставления «столица - провинция», первая соответственно ассоциируется со значительностью и динамичностью, вторая - со второстепенностью и «неподвижностью», где любая новация немедленно становится «курьезом», забавой. Сегодня, - подчеркивает исследователь, - преодолеваются эти представления о провинции как синониме «остановленного» времени и «застывшего» пространства, миссия которой заключается лишь в том, чтобы быть истинной хранительницей традиции и находиться в обязательной оппозиции столице. Мир российской провинции в значительной степени определяет модель русской культуры, а любые новации в столицах неизбежно сталкиваются, соприкасаются с особенностями провинциальной культурной среды [19]. По убеждению В. Каганского, инновации приживаются в провинции трудно: «Внедрение экзотических и просто новых ... технологий и элементов ландшафта в провинциальную среду весьма затруднено в силу ее инертности, консервативности, но, прежде всего, полноты

\footnotetext{
* Статья подготовлена по теме НИР «Регион в контексте российской истории: ландшафты и акторы (концептуальнометодологические и источниковедческие аспекты)».
}

социокультурной структуры (нет свободных социальных ниш). Однако новые элементы ландшафта взимопригоняются и приспосабливаются именно в Провинции, именно здесь они становятся понастоящему укорененными, отечественными, «родными» - без адаптации в Провинции невозможна и их трансляция на периферию» [10, с. 249]. Особую роль города в складывании историко-культурного пространства российской провинции подчеркивают многие историки. По убеждению Н. М. Инюшкина, город творит самосознание провинции; именно города от имени провинции вступают в диалогические отношения со столицей, в них осуществляется активный информационный обмен между людьми. М. Л. Каган предлагает учитывать противоречивое положение провинциального города, существующего в поле притяжения двух сил - столичных и деревенских [35, с. 78]. Таким образом, состояние современной историографии свидетельствует об актуальности изучения культурного ландшафта российского провинциального города. Статья нацелена на исследование процесса его эволюции в контексте внедрения «столичных» технических инноваций и строится на региональных, в значительной степени, уральских, материалах последних десятилетий XIX - начала XX в.

Изменения в быту горожан, эволюция городской инфраструктуры в имперской России в целом во многом определялись новинками, распространявшимися из-за рубежа [2, с. 138-174]. В то же время, необходимо подчеркнуть, что этот процесс не был однонаправленным. Например, достигнутые в XIX в. русскими учеными и инженерами успехи в области электротехники, имели своим следствием 
освещение улиц и зданий мировых столиц, в том числе, Парижа электрическими «свечами Яблочкова». Однако все же чаще и, как правило, относительно быстро, именно западные, столичные новшества проникали в повседневную жизнь российской провинции. Прогресс и новации стали наиболее заметны в городах в последние десятилетия XIX - начале $\mathrm{XX}$ в., когда под влиянием научно-технического прогресса в социокультурной жизни города происходили существенные изменения, а сами города заметно благоустраивались, меняя привычный культурный ландшафт. Представляется важным показать масштабы и скорость распространения социально значимых передовых технических нововведений в отдаленных регионах России в этот период, определить степень их влияния на городскую повседневность и отношение к ним горожан.

Если на поэта П. А. Вяземского, побывавшего на Урале в начале XIX в., Пермь и другие города Прикамья произвели жалкое впечатление, то другой очевидец, спустя три четверти столетия, писал: «Города Чистополь, Елабуга, Сарапул и Пермь стоят в иных уже условиях. Везде... заметна забота об удобствах и приспособлениях к лучшей обстановке жизни. Если бы Вяземский был жив и проехал теперь на одном из блестящих пароходов, принадлежащих прикамским же жителям, он, наверное, не узнал бы прежнего... прикамского края и, вероятно, вместо сожаления об убожестве этого края, воспел бы ему хвалебную песнь...» [32, с. 157].

Показательно, что в сознании горожан прогресс ассоциировался именно с европейским влиянием. Автор публикации «Мечты и действительность сарапульцев» (с подзаголовком «Европейские мечты наших отцов и азиатская действительность города»), опубликованной в «Приложении к Вятским губернским ведомостям» 6 июля 1899 г., писал, что городская дума Сарапула «не спит и бредит, чтобы сделать Сарапул настоящим европейским городом. У нас начинают мостить... третью улицу; в скором времени будет телефон, и мы будет разговаривать друг с другом и отдавать приказания подчиненным утром и после обеда, не вставая с постели; наконец, лет двадцать спустя, мы будем гулять в «городском Пушкинском сквере» $[25$, с. 3]. В словах современника сквозила нескрываемая ирония, слишком далека была азиатская действительность от европейских идеалов. Тем не менее, технический прогресс неумолимо и достаточно быстро распространял свое влияние на города и веси Российской империи.

Пожалуй, самой значимой технической новацией рассматриваемого периода, шире - наиболее заметным маркером современного образа жизни - является применение электричества для индивидуального, уличного и производственного освещения, приведения в действие различных рабочих механизмов, транспортировки пассажиров и грузов, передачи информации, в бытовой технике. Использование электричества в городской инфраструктуре - характерная черта современного города, отличающая его от всех остальных исторических типов поселений человека. Совершенствование механизмов получения электричества и разработки наиболее эффективных осветительных приборов имеет долгую историю, которая объемлет переход от постоянного тока к переменному, дуговые лампы и лампы накаливания и многие другие оригинальные технические решения. Первый опыт освещения Парижа с помощью электричества был проведен в 1843 г. на площади Согласия [15, с. 316]. В 1873 г. Александр Лодыгин экспериментировал с освещением лампами накаливания улиц Петербурга. В этом же году «весьма любопытные опыты» по электрическому освещению производились в Лондоне в Вестминстере [39, p. 158]. В 1878 г. в Лондоне электричество впервые применили для освещения набережной, затем района Биллинсгейтс, нескольких театров и Холборнского путепровода [37, p. 389]. В 1878 г. центральные площади и улицы Парижа, в котором проходила Всемирная выставка, освещались «свечами Яблочкова». В 1879 г. электрические фонари - впервые в мире - были установлены в Петербурге на мосту Александра II (ныне Литейном).

Однако это были лишь первые подходы к решению задачи длительного, бесперебойного и эффективного освещения значительного городского пространства. Только после того, как Т. Эдисон, доработав лампу накаливания с угольной нитью, создал практически применимую электрическую систему, в 1880-е гг. электрическое освещение стало быстро распространяться в бурно развивавшихся европейских, американских городах, на территории Российской империи. Для выработки электроэнергии строятся электростанции: в 1883 г. Томасом Эдисоном построена первая электростанция в Лондоне, в этом же году в Петербурге на деревянной барже, пришвартованной на реке Мойке у Полицейского моста и рядом с Казанской площадью заработали две электростанции общего пользования [18]. В 1883 г. фирма Сименса «осуществила электрическое освещение Невского проспекта и в течение 13 лет не требовала от Городской думы денег на его эксплуатацию; через несколько лет осветила электричеством Зимний дворец, устроив электростанцию в его подвале. В последующие годы электрический свет получили здания Консерватории, Института экспериментальной медицины, детского приюта принца П.Г. Ольденбургского. Эти и ряд других электротехнических работ фирма выполнила безвозмездно» [36, с. 110]. Царское Село в 1887 г. стало первым европейским городом, полностью освещенным электричеством.

В Москве первые электрические фонари появились в 1880 г. В 1882 г. в новом здании театра Корша в Камергерском переулке было проведено электрическое освещение сцены, зрительного зала, фойе и артистических уборных. В мае 1883 г., в дни коронации Александра III, при помощи дуговых ламп была освещена площадь вокруг Храма Христа Спасителя и впервые подсвечивалась колокольня Ивана Великого. Первая московская электростанция на ул. Большая Дмитровка (1888 г.) производила постоянный ток. В ноябре 1897 г. на Раушской набережной начала вырабатывать переменный ток электростанция, построенная акционерным «Обществом электрического освещения 1886 года». Однако даже в центре города еще долго соседствовали 


\section{Исторические науки}

газовые, газокалильные и дуговые электрические светильники, а окраины освещались керосиновыми фонарями. В 1910 г. в городе действовало 440 дуговых электрических фонарей и шесть опытных с лампами накаливания. В 1913 г. из 20842 уличных светильников, установленных на улицах и площадях Москвы, 7806 были газовыми, 9029 - керосиновыми и 4007 - электрическими. Весь город обслуживали 2 электростанции общей мощностью в 66,5 тыс. квт. Лишь к 1926 г., в результате реализации плана ГОЭЛРО все керосиновые фонари в Москве были заменены электрическими, а в 1932 г. были ликвидированы последние газовые фонари [17].

Фиксируя перемены в освещенности столиц, стоит заметить, что параллельно с появлением электричества в городах, а зачастую и опережая его, развивается электроэнергетика в промышленности. Лампы П. Н. Яблочкова использовались не только для иллюминации крупных городов, но и на производстве - уже в 1880 г. они освещали мастерские Днепровского пароходства. Благодаря электростанции, построенной по проекту Н. Г. Славянова на Пушечных заводах в 188687 гг., Пермские пушечные заводы одними из первых в России перешли на электрическое освещение, а в 1890 г., также по методу Н. Г. Славянова, здесь был введен процесс электродуговой сварки [21, c. 306]. В Сибири, на Алтае, первая промышленная электростанция была построена горным инженером Н. Н. Кокшаровым в 1892 г. на Зыряновском руднике [1, c. 19].

На страницах периодических изданий провинциальные обыватели могли почерпнуть информацию об истории электрического освещения, в развитие которого внесли свой вклад зарубежные и отечественные ученые. В статье, опубликованной, например, в «Приложении к Вятским Губернским Ведомостям» повествовалось о принципах систем электрических источников света и способах их изготовления. Ее автор подчеркивал, что над изобретением хорошо действующего регулирующего механизма трудились многие ученые и механики Старого и Нового Света, среди которых видное, если не первое, место заняли с самого же начала русские люди. Так, с именем саратовского уроженца П. Н. Яблочкова, связано изобретение т. н. “электрической свечи”, а известному изобретателю Чиколеву принадлежит устройство ныне распространенной дифференциальной дуговой лампы» [27].

Практически одновременно с крупными европейскими городами и российскими столицами, уже во второй половине 80-х гг. XIX в. жители Екатеринбурга познакомились с электрическим освещением, которое существовало «в театре, на дачах для гулянья, на симановской мельнице и в некоторых частных домах» [6, с. 85-86]. Первая электроустановка заработала в 1885 г. во дворе Первого городского театра. Газета «Екатеринбургская неделя» писала об этом: «Да, можно сказать, опера идет прекрасно. Конечно, обстановка несколько хромает, но зато электрический свет, обильно разливающийся по театру, вознаграждает публику, потухая внезапно в патетических местах для придания эффекта некоторым сценам, заставляя нервных дам вскрикивать и вскакивать» [3, с. 74]. Электричество освещало поначалу только театральную сцену и зал, а на следующий год и прилегающую к зданию улицу. «Театральный перекресток» проспектов Главного и Вознесенского стал первым участком города, освещенным электричеством. Первую городскую электростанцию (здание которой сохранилось в Екатеринбурге до сих пор) построило «Товарищество электрического освещения в Екатеринбурге А. Елтышев, инженер Н. Панфилов и $\mathrm{K}^{0}$ » в 1894 г. $[3$, с. 68]. Из-за конкурентной борьбы между поставщиками электрического оборудования и по техническим причинам, связанным с неравномерной нагрузкой сети, некоторые учреждения предпочитали автономную выработку электричества. Так, в 1913 г. электрическое освещение в Екатеринбургской гостинице «Пале-Рояль» производилось двумя двигателями внутреннего сгорания, один из которых приводил в действие динамо-машину постоянного тока для освещения гостиницы, другой обеспечивал электротеатр «Варьете» [14, с. 106]. Тем не менее, многочисленные факты свидетельствуют о том, что на рубеже XIX - XX вв. электричество в Екатеринбурге «стало неотъемлемой частью городского образа жизни: оно использовалось как для освещения улиц и площадей, так и частных домов, зданий различных учреждений, клубов и т. д.» [16, с. 120].

Как и в крупных европейских городах, на улицах горнозаводской столицы Урала довольно продолжительный период соседствовали фонари разных устройств. В конце 1880-х гг. с 15 августа по 1 мая Екатеринбург освещался 355 обыкновенными керосиновыми фонарями. Стоимость содержания каждого фонаря колебалась в пределах 9-11 руб. В 1895 г. для освещения улиц в Екатеринбурге стало применяться электрическое освещение. В 1901 г. город освещался 94 дуговыми фонарями, час эксплуатации которого стоил 6,5 коп. Однако из-за перебоев с подачей электроэнергии, городская управа предусмотрительно занималась ремонтом керосиновых фонарей и ламп, чтобы «иметь возможность освещать улицы при неисправном действии электричества» [20, с. 297].

Во второй половине XIX - начале XX в. эволюционировала технология уличного освещения и в Уфе. Если в 1861 г. улицы Уфы освещали спиртовые фонари, то со временем их сменили керосиновые, а в феврале 1898 г. в городе заработала электрическая станция, и зажглись первые электрические дуговые фонари. Пятьдесят дуговых фонарей освещали центральные улицы города [9, с. 209-210].

Вопрос об устройстве электрического освещения Перми обсуждался городским управлением начиная с 1896 г., но городская центральная электрическая станция была открыта только в 1902 г. На ее устройство потребовалось 107403 руб. 93 коп. При открытии к станции подключилось 50 абонентов, а к концу года их число увеличилось до 182 (с общим количеством лампочек — 4432). К концу 1902 г. сеть уличного освещения включала 20 дуговых фонарей и 127 ламп Нернста [4]. А. И. Фирсов, побывав в Перми, удивлялся: «Ни в одном губернском городе я не видел такого большого количества фонарей, расставленных на улицах, как именно в Перми. Во- 
обще пермяки питают слабость к электричеству: они осветили им не только собор, но и все приходские церкви, а в домах поместили более чем необходимо электрических лампочек» [24, с.264].

В конце 1902 г. на страницах местной периодики сообщалось о решении Вятской городской думы устроить в городе электрическую центральную станцию для освещения частных и общественных домов, главных улиц и площадей. Это дало возможность современнику утверждать, что «прогресс и культура» не чужды городу. «И вот спустя сорок лет, - рассказывал он, - после того, когда город не имел средств даже на самое скромное освещение, прибегая к воззванию о пожертвовании, мы будем иметь удовольствие гулять в ночное время при электрическом освещении городских улиц, устроенном на счет города» $[29$, с. 1]. В следующем году местная газета констатировала: «Постройка электрической станции и устройство электрических проводов подвигается быстро и к октябрю будет, вероятно, закончена, если не встретится каких-либо препятствий» $[28$, с. 4$]$.

В начале XX в. о необходимости замены керосинового уличного освещения электрическим в уездных городах заговорили все настоятельнее. Так, из отчета Шадринской городской управы за 1913 г. следует, что в это время город освещался 28 керосинно-калильными фонарями. Шадринцы понимали, что лучшим, удобным и более практичным уличным освещением нужно считать электрическое. В отчете управы за 1913 г. отмечалось, что к его устройству городом «направлены все меры». Вопрос об устройстве электрического освещения обсуждался в это время и на заседаниях городской думы и управы г. Осы. В июльском номере газеты «Уральская жизнь» за 1914 г. сообщалось, что электрическая станция в Осе должна появиться к осени 1915 г. [29, с. 2].

Распространение электричества на Южном Урале тормозилось из-за дороговизны электрооборудования и медленного строительства электростанций. Если одна из первых в регионе электростанция в Уфе начала работать ещё в 1898 г., то в Шадринске в 1914 г. только обсуждали вопрос о её сооружении. Переход на новый вид энергии растянулся на Южном Урале на продолжительное время. Кроме того, первые электростанции были не готовы к значительным нагрузкам. Например, в Челябинске функционировала частная электростанция «Колбин и Кокарев». По оценкам современников, часто наблюдались перебои с подачей ею электричества, неисправности в работе телефонной сети, да и стоимость электрической энергии была высокой 40 копеек за киловатт-час. В Оренбурге электростанция, построенная в 1899 г., тоже первоначально не могла удовлетворять растущие потребности города [7, c. $28-31]$.

Электричество в Азиатской России распространялось, конечно, не «со скоростью света», но поразительно быстро для рассматриваемого времени и учитывая масштабы Российской империи. Известный русский военный дипломат и писатель А. А. Игнатьев, вспоминал о своем посещении Красноярска летом 1885 г.: «Пыльные, грязные, вылезли мы из нашей кибитки и очутились в каменном двухэтажном «дворце» купца Гадалова, освещенном электрическим светом, которого я никогда до тех пор не видал. Ведь в Питере еще только хвастались новыми керосиновыми горелками» [8, с. 35]. Свидетельство А. А. Игнатьева подтверждает А. П. Чехов, проезжавший через Красноярск в мае 1890 г. Обращаясь к доверенному Н. Г. Гадалова Ноздрину, он уточнил: «Мне на станции сказали, что у Гадалова в доме своя электрическая станция имеется. Признаться, я не поверил тому... Сибирь, знаете ли - и электричество! Решил убедиться лично». Антон Павлович побывал на станции, с интересом выслушал объяснение механика, сам включил освещение. Электрический свет, удививший столичных гостей, загорелся в Сибири одновременно с центром России и немного позже, чем в Западной Европе [1, с. 30-31]. Дом и магазин Н. Г. Гадалова освещали 59 ламп накаливания по 16 свечей системы Эдисона. Топливом для локомобиля служили уголь или дрова [11, с. 168].

Вопрос о строительстве центральных городских электростанций общего пользования поднимался в восточных городах Российской империи практически одновременно с их появлением в Лондоне, Париже, Петербурге, городах Урала. Так, в 1886 г. иркутский городской голова распорядился составить смету на устройство общегородского освещения. Однако претворение проектов в жизнь надолго задерживалось из-за отсутствия средств, инертности традиционного сознания, высчитывавшего, будет ли электрическое освещение лучше газового и керосинового, концессионным или хозяйственным способом лучше строить электростанцию, какова будет доходность предприятия и т.д. В результате, Иркутская городская электростанция вступила в строй лишь в 1910 г. Другие сибирские электростанции были пущены: в Томске в 1895 г., в Верхнеудинске, Сретенске, Канске, Тюмени, Чите в 1905-1908 гг., в Красноярске в 1912 г., в Новониколаевске в 1913 г., в Якутске в 1914 г. [1, с. 32].

Также в конце XIX - начале XX в. электричество пришло в города Дальнего Востока. Первые небольшие электростанции появились в 1890-х гг. во Владивостоке и в Благовещенске в магазинах и конторах торговых домов, в Хабаровске - в казармах саперного батальона. Городские электростанции были пущены: в 1906 г. — в Хабаровске, в 1907 г. — в Благовещенске, в 1909 г. — в НикольскеУссурийском, в 1910 г. - в Николаевске-на-Амуре, в 1912 г. - во Владивостоке. Важно подчеркнуть, что «электрическое освещение появилось не только в общественных, административных зданиях, торговых заведениях, но и в частных жилищах; на улицах городов были установлены электрические фонари, хотя на окраинах продолжали сохраняться и керосиновые. В Хабаровске, например, в 1911 г. в домах горожан горело уже 12000 электрических лампочек, а на улицах города в 1913 г. - 54 электрических фонаря, 15 керосиновых и 20 керосино-калильных фонарей» [23, с. 106]. На Дальнем Востоке, как и в других городах, одними из первых стали оснащать свои заведения электрическим освещением и современными удобствами владельцы лучших гости- 


\section{Исторические науки}

ниц. В 1897-1900 гг. во Владивостоке «по образцу лучших отелей Европы» были устроены гостиницы «Золотой Рог» и «Тихий океан», в Благовещенске «Центральная гостиница» [23, с. 106].

Новый вид энергии - электрический, сначала использовался для освещения улиц, магазинов, особняков, мест общего пользования. Однако практически одновременно электричество стало применяться на транспорте — уже в 1880-е гг. появляется и активно развивается трамвайное сообщение. В 1881 г. первый трамвай, построенный компанией «Сименс и Гальске», пошел в Берлине и в Париже. В 1885 г. трамвай появился в английском Блэкпуле. В Российской империи трамвай был пущен в Киеве в 1892 г., затем в целом ряде провинциальных городов (в 1896 г. в Нижнем Новгороде, в Екатеринославе и Елисаветграде в 1897 г., в Курске, Витебске, Севастополе и Орле в 1898 г., в Москве, Житомире, Либаве, Казани и Кременчуге в 1899 г., в Астрахани, Ярославле и Екатеринодаре в 1900 г., в Риге, Ростове-на-Дону, Твери и Смоленске в 1901 г., в Пятигорске в 1903 г., во Владикавказе в 1904 г., в Санкт-Петербурге в 1907 г., в 1912 г. во Владивостоке. Провинциальные города опережали столичные, поскольку в них не было столь сильного противодействия конкурентов - владельцев конок, практически монополизировавших до появления электрических трамваев рельсовый вид городского транспорта.

На Урале и в Сибири также рассматривалась проблема внедрения нового вида транспортного сообщения. Челябинская городская дума вела поиски проектов устройства конно-железной дороги и электрического трамвая с 1906 г. Городской власти приходилось учитывать как вопросы рентабельности, так и противодействие извозчиков, опасавшихся лишиться своих заработков [7, с. 24]. Летом 1907 г. в Пермской городской думе обсуждался вопрос о проведении трамвая от железнодорожной станции вновь строящейся железной дороги до Мотовилихи $[34$, C. 140]. Екатеринбургская городская дума рассматривала возможность внедрения трамвайного транспорта на заседании в январе 1909 г. [33, с. 2]. Прогрессивно мыслящие горожане и особенно пресса поддерживали начинание. Корреспондент газеты «Уральский край» писал: «Устройство в городе Екатеринбурге трамвая, известие о котором проникло в недавнее время в печать, многим обывателям показалось заманчивым и желательным». Современник отмечал, что размеры города Екатеринбурга с его пригородами, значительность торгового оборота и многие другие факторы создавали благоприятные условия для реализации этого предприятия: «Мы не сомневаемся, что устройство трамвая своевременно, что это предприятие, будучи поставлено разумно, будет развиваться и нужно приложить немного стараний, чтобы найти солидных предпринимателей» $[22$, с. 12]. Однако в действительности на тот момент городское самоуправление финансово было не в состоянии реализовать идею. К проектам о введении трамвайного сообщения гласные вернулись накануне Первой мировой войны. [30, с. 2-3]. Аналогичные дискуссии шли и в Сибири: в Иркутске рассматривали проект устройства трамваев в 1896 г,, в Новониколаевске — в 1914-1916 гг., неоднократно об устройстве трамвайного сообщения дискутировали в Томске и Омске [1, с. 37-38]. Однако Первая мировая война и последующие революционные события заставили заняться другими актуальными вопросами городской жизни, надолго отложив проекты о внедрении трамвайного сообщения. В результате трамваи стали ходить по уральским и сибирским городам уже только в советскую эпоху.

Энергия электричества применялась и в новых видах связи - общегородской культурный ландшафт пополнился телефоном. В 1885 г. первые телефонные кабины общего пользования были установлены в Париже. В этом же году министр почт и телеграфа Франции Кошри принимал личное участие в эксперименте по соединению телефонной связью городов Руана и Гавра, находящихся на расстоянии 90 км [38, p. 94]. В России в быт городских слоев телефон стал входить в начале 1880-х гг. Вскоре после его изобретения в Америке образовавшееся вокруг Белла акционерное общество взяло несколько концессий на устройство телефона в русских городах. Внутригородская телефонная связь начала распространятся с 1881 г. В России к 1885 г. телефон был установлен в 6 городах, в 1910 г. — в 314.

В Екатеринбурге телефон появился в 1884 г. во многом благодаря городскому голове И. И. Симанову. Телефонная линия соединила городскую управу и полицейскую часть. Первая в Екатеринбурге телефонная станция вступила в строй 10 марта 1892 г. Абонентов было немного - перед Первой мировой войной в городе насчитывалось всего 600 номеров [3, с. 60]. Также в 1892 г. открылась телефонная станция в Перми. В 1897 г. начала действовать ГТС в Уфе, а в следующем - в Сарапуле и Оренбурге [6, с. 85-86]. К 1906 г., когда телефоны были установлены в 95 городах России, число абонентов телефонных станций достигло 26 тыс. [12, с. 703].

Применение электроэнергии положительно сказалось и на развитии телефонных сетей Южного Урала. В Челябинске в 1905 г. первоначально было всего 63 телефонных абонента. Для большинства челябинцев установка телефона была не доступна из-за его высокой стоимости (за подключение к сети нужно было уплатить 16 руб. с каждого установленного аппарата). Особую ситуацию можно было наблюдать в Оренбурге. Город имел важное военностратегическое значение, в нем была установлена правительственная телефонная сеть. Оренбуржцы начали пользоваться телефоном с 1897 г., к 1914 г. количество абонентов составило 550 человек.

Городская телефонная сеть Шадринска была открыта 20 декабря 1910 г. К началу 1911 г. насчитывался 51 абонент, а к концу года - 71. Развитие сети не смогла остановить даже высокая плата за телефон - 18 руб., увеличившаяся в 1913 г. до 24 руб. за каждый аппарат. Дороговизна пользования телефоном в Шадринске объясняется тем, что сеть была частной, а городская власть не принимала финансового участия при ее создании, все материальные затраты легли на плечи самих абонентов, пользовавшихся связью. В Троицке в 1913 г. было зарегистрировано 109 абонентов и 113 аппаратов $[7$, c. $13-33]$. 
Противоречивое отношение современников к новым видам связи объяснялось зачастую скудостью городских бюджетов и ростом разнообразных общественных потребностей. Житель Сарапула, например, писал: «Телефон, конечно, вещь хорошая и, главное, непременная принадлежность в собственном смысле европейского города. Когда он будет, наконец, в Сарапуле, то мы сразу шагнем в XXI столетие и уже куда до нас какой-нибудь Елабуге... Но я бы не советовал городу торопиться и с телефоном. Не подумайте, что я азиат и противник прогресса. Нет. Но поторопитесь лучше с мостовыми, со сквером, с народной аудиторией, а главное - с пушкинской или хотя бы и не пушкинской школой» [25].

И все же, телефон начинал пользоваться все большей популярностью. В 1902 г. на страницах августовского номера приложения к «Вятским губернским ведомостям» подробно рассказывалось о таком «полезном нововведении» как устройство телефона в Вятке, сообщалось, что оно будет завершено в первых числах сентября этого же года. Устройство телефонной сети в Вятке осуществлялось местным городским управлением с разрешения Главного управления почт и телеграфов. На заседании 1 апреля 1902 г. городская дума установила ежегодную абонементную плату в возмещение расходов городского управления по содержанию центральной станции и телефонной сети в размере 30 руб. за год. На момент открытия городской центральной телефонной станции насчитывалось 86 абонентов. Это были различные административные и иные учреждения, владельцы магазинов и частные лица [26, c. 3].

В это же время телефонная связь распространилась и на Дальнем Востоке. В Хабаровске в конце 1890-х гг. существовала «военная телефонная связь, станция которой находилась в окружном штабе, в сентябре 1900 г. к этой сети подключились административные учреждения. Городская же сеть начала действовать с 1905 г. В 1906 г. телефоном пользовались 155 абонентов, в 1910 г. - 520. Владивостокская городская телефонная сеть была построена в 1907 г., до этого существовала сеть, связывавшая главные административные, военные, портовые учреждения». Число абонентов быстро росло: с 478 в 1907 г. до 1403 в 1919 г. «В Никольске-Уссурийском телефон в административных учреждениях появился 15 ноября 1912 г. Телефон в дальневосточных городах существенно улучшил бытовые условия состоятельных горожан, ускорил решение насущных проблем: по телефону можно было записаться к врачу или вызвать его на дом, позвонить в полицию или пожарную часть и др.» [23, с. 109-110]. И всё же, для широких кругов населения телефон был малодоступен. Даже в 1920 г. в стране на 1 тыс. жителей приходилось 1,5 телефона, в то время как в США 131,1 , а в Германии - 33,3 [31, с. 134].

В заключение следует отметить, что технический прогресс в рассматриваемый период двигался совместными усилиями русских и иностранных инженеров, которые активно контактировали между собой лично, постоянно следили за публикациями в многочисленных специальных изданиях, опера- тивно сообщавших о новейших достижениях и изобретениях. Эти связи стимулировали отечественную инженерно-техническую мысль, позволяли русским специалистам вести исследования на передовом международном уровне, внедрять разработки в повседневность в России и за рубежом. Несколько лет работал во Франции, а затем уехал в Америку А. Н. Лодыгин, лампу накаливания которого усовершенствовал впоследствии Т. Эдисон. П. Н. Яблочков, создавший работавшую без регулятора дуговую лампу, участвовал в технических выставках в Англии, Франции, а его «русский свет», осветивший сначала магазин в Лувре, ипподром, театр Шатле, площади и улицы Оперы в Париже, распространился по всей Европе. И напротив, российским городам и весям хорошо были знакомы фирма «Сименс и Гальске», лампы накаливания В. Нернста и Т. Эдисона.

Потребность в технических инновациях, сближавших провинциальные города со столичными, а также результаты их внедрения заметнее проявлялись в городах губернского значения. Прогрессивные изменения в бытовой сфере российского провинциального города обусловливались как активной деятельностью органов городского самоуправления по улучшению городского благоустройства, так и развитием экономики и культуры городов, столичным и европейским культурным влиянием. Трудности с внедрением некоторых технических инноваций проистекали из скудости городских бюджетов. И все же города росли, обзаводились электростанциями, на центральных улицах, в общественных зданиях и частных домах вечерами загорались электрические фонари и лампочки. Горожане приобщались к новым средствам коммуникации. Городской ландшафт эволюционировал постепенно, вбирая в себя технические новшества, которые еще долго соседствовали с привычным, традиционным. Неудивительно, что впечатления современников о городах восточной части империи были противоречивы. Так, в своей книге «По Европе и России» В. А. Поссе в 1907 г. отмечал контрасты, присущие Екатеринбургу: казенные учреждения, отстоящие друг от друга на целые версты, «широкие улицы с красивыми зданиями, электрическое освещение, телефоны, театры, увеселительные сады, но нет не только трамвая, но и самой примитивной конки, нет и водопровода, а вместе с тем и поливки улиц, так что в летние дни не только бедняки пешеходы, но и богачи, разъезжающие на своих рысаках, положительно купаются в пыли. Три большие прогрессивные газеты, несколько ученых обществ, библиотеки имени Белинского и Решетникова, и наряду с этим «всесословное пьянство»... [5, с. 163$].$

Очевидно, что появление и все более широкое распространение электричества заметно повлияло на эволюцию культурного ландшафта российского провинциального города, кардинально изменив облик губернских и уездных городов восточных регионов России, причем по времени все эти перемены начинались в унисон и лишь немного позже, чем в европейских и российских столицах. Однако городской элите и городским властям провинциальных городов приходилось преодолевать значительно больше трудностей для введения новинок, степень 


\section{Исторические науки}

их распространения была ограниченной по объективным причинам (не только материальным, следует учитывать и ментальные особенности провинциальных обывателей), распространение новаций на просторах империи растягивалось на годы и даже десятилетия.

\section{Литература и источники}

1. Алексеев, В. В. Электрификаиия Сибири. Историческое исследование. - Ч. I. 1885-1950 / В. В. Алексеев Новосибирск : Наука, 1973. - 312 с

2. Алексеева, Е. В. Европейская культура в имперской России. Проникновение, распространение, синтез / Е. В. Алексеева - Екатеринбург : Изд-во УрГИ, 2006. $254 \mathrm{c}$.

3. Бердников, Н. Н. Город в двух измерениях / Н. Н. Бердников - Свердловск : Сред.-Урал. кн. изд-во, 1979. $-112 \mathrm{c}$

4. ГАПО. Ф. 35. Оп. 1. Д. 130. Л. 14 об. -15 об.

5. Грамолин, А. И. Екатеринбург - Свердловск Екатеринбург. История городской власти (1745-1919): документально-публицистические очерки / А. И. Грамолин, Э. А. Коридоров - Екатеринбург : Сред.-Урал. кн. изд-во ; Новое время, 2003. - $171 \mathrm{c}$.

6. Екатеринбург. Исторические очерки (17231998). - Екатеринбург : Екатеринбург, 1998. - 228 c.

7. Ерыкалина, А. Ю. Культурная жизнь городского населения Южного Урала (конеи ХІХ в. - 1914 г.) / А. Ю. Ерыкалина : дис. ... канд. ист. наук. - Челябинск, 2015. - $195 c$.

8. Игнатьев, А. А. Пятьдесят лет в строю: в $2 \mathrm{~m}$. A. А. Игнатьев. - T. 1. - Кн. 1-3. - М. : Правда, 1989.- 448 c.

9. Из истории феодализма и капитализма в Башкирии. Уфа : Башкирский филиал АН СССР, 1971. — 437 c.

10. Каганский, В. Россия. Провинция. Ландшафт / B. Каганский// Отечественные записки. - 2006. № 5. - C. 244-257.

11. Кибардин, В. В. История строительства первых электрических станиий г. Красноярска / В. В. Кибардин // Вестник Красноярского государственного аграрного университета. - 2011. - № 6. - C. 168-174.

12. Кочман, Л. В. Художественная культура «Серебряного века» / Л. В. Кошман // Россия в начале XX в. М. : Новый хронограф, 2002. - С. 695-708.

13. Кудрявиев, В. Старина, памятники, предания и легенды Прикамского края / В. Кудрявиев // Памятная книжска и календарь Вятской губернии на 1899 год. Вятка, 1898.

14. Лузин, Г. А. Описание двигателей внутреннего сгорания на некоторых заводах Урала, с кратким очерком развития, действия и назначения этих машин (извлечение из отчета по командировке) / Г. А. Лузин // Горный журнал. - 1913. - № 1-2. - 109-148.

15. Мильчина, В. А. Париж в 1812-1848 годах: повседневная жизнь / В. А. Мильчина. - М. : Новое литературное обозрение, 2013. - 944 c.

16. Микитюк, В. П. Повседневная жизнь Екатеринбурга на рубеже XIX-XX веков. Очерки городского быта / В. П. Микитюк, О. Н. Яхно. - Екатеринбург : АМБ, 2014. - $488 c$.

17. Музей городского освещеения "Огни Москвы»». URL: http://testan.narod.ru/museum/ogny.htm (Дата обращения: 15.03.2017).
18. Музей истории энергетики Северо-Запада. URL: http://www.energomuseum.ru/timeline/nachalo-ehryehlektrichestva/ (Дата обрашения: 15.03.2017).

19. Отставнова, И. В. Пространство российской провиниии: «Жизнесмыслы» : дис. ... канд. культ. / И. В. Отставнова. - Саранск, 2006. - 150 c.

20. Отчет Екатеринбургской городской управы о движении сумм, капиталов и имущества г. Екатеринбурга за 1901 год. - Екатеринбург, 1903.

21. Отчет по командировке горного инженера М. М. Федорова. Очерк состояния электрических сооружений на уральских заводах и рудниках в 1906 г. // Горный журнал. - 1910. - T. IV. - № 12. - C. 286-319.

22. По вопросу об устройстве трамвая в Екатеринбурге // Уральский край. - 1909. - № 12.

23. Позняк, Т. З. Жилье и быт горожан на дальневосточной окраине (вторая половина XIX - начало XX в.). / Т. 3. Позняк // Известия Алтайского государственного университета. - № 4-1. - 2008. - C. 103-111.

24. По Каме и Уралу: путевые записки XIX - начала ХХ вв. - Пермь : [б. и.], 2011. - 296 с.

25. Приложение к Вятским Губернским Ведомостям. Газета общественная и литературная. - 1899. № 78. - 6 июля.

26. Приложение к Вятским Губернским Ведомостям. Газета общественная и литературная. - 1902. № 101. -24 авг.

27. Приложение к Вятским Губернским Ведомостям. Газета обшественная и литературная. - 1902 г. № 138 . -19 нояб.

28. Приложение к Вятским Губернским Ведомостям. Газета общественная и литературная. - 1903. № 73. -24 июня.

29. Приложение к Вятским Губернским Ведомостям. Газета общественная и литературная. - 1903. № 94 . -12 авг.

30. Проект электрического трамвая // Зауральский край. - 1913. - № 37. - 14 февр.

31. Россия в начале $X X$ в. - М. : Новый хронограф, 2002. $-742 c$.

32. Смышляев, Д. Сборник статей о Пермской губернии / Д. Смышиляев. - Пермь, 1891.

33. Трамвай в Екатеринбурге // Уральский край. 1909. - № 10.

34. Трапезников, В. Н. Летопись города Перми / В. Н. Трапезников - Пермь : Гос. архив Пермской обл., 1998. - $272 c$

35. Цыганова, Я. М. Российская провиничи пореформенной эпохи как историко-культурное пространство: подходы к изучению / Я. М. Цызанова // Вестник СамГУ. 2013. — № 8/2 (109). — C. 74-82.

36. Чеснокова, А. Н. Иностраниы и их потомки в Петербурге: Немиы. Франиузы. Британиы (1703-1917) / А. Н. Чеснокова. - СПб. : САТИС, 2003. - 335 c.

37. Ackroyd, P. London. The concise biography / P. Ackroyd. - London: Vintage Books, 2012. - 688 p.

38. La Nature. Revue des Sciences. 1885. Treizième année, premier semester. $n .601$ à 626. P. 94. - URL: http://cnum. cnam.fr/CGI/fpage.cgi? 4KY28.24/3/100/432/8/420 (Дата обращения: 4.02. 2017).

39. Une nouvelle lumière électrique à Londres // La Nature. Revue des Sciences. 1873. Première année: n. 1 à 26. P. 158. - URL: http://cnum.cnam.fr/CGI/fpage. cgi? 4KY28.24/3/100/432/8/420 (Дата обращения: 4.02. 2017).

Поступила в редакцию 22 мая 20172. 
АЛЕКСЕЕВА Елена Вениаминовна, профессор РАН, доктор исторических наук, ведущий научный сотрудник, Институт истории и археологии Уральского отделения РАН (Екатеринбург, Россия). E-mail: alekseeva167@mail.ru

КАЗАКОВА-АПКАРИМОВА Елена Юрьевна, доктор исторических наук, доцент, ведущий научный сотрудник, Институт истории и археологии Уральского отделения РАН (Екатеринбург, Россия). E-mail: apkarimova@mail.ru

Bulletin of the South Ural State University Series "Social Sciences and the Humanities» 2017, vol. 17, no. 3, pp. 6-14

\title{
TECHNICAL INNOVATIONS AND EVOLUTION OF CULTURAL LANDSCAPE IN RUSSIAN PROVINCIAL CITIES AT THE END OF THE XIX - EARLY XX CENTURY
}

\author{
E. V. Alekseeva, Institute of History and Archaeology, Ural Branch, RAS, \\ Ekaterinburg, Russian Federation, alekseeva167@mail.ru

\section{E. Yu. Kazakova-Apkarimova, Institute of History and Archaeology, Ural Branch, RAS, Ekaterinburg, Russian Federation, apkarimova@mail.ru}

\begin{abstract}
The article dwells on the evolution of the cultural landscape of the Russian provincial towns in the late nineteenth and early twentieth centuries in the context of the introduction of technical innovations. The cities are seen as important actors in the socio-cultural and technical progress of the Russian province. The need to introduce technical innovations that bring the provincial settlements closer to the capitals was stronger in the county cities. The authors turn to the history of introduction of electricity in the cities of the eastern regions of Russia, analyzing its multifaceted application in everyday life. The topic under study fits into the global context. Researchers show that Russian cities (not only the capitals, but many provincial cities as well) did not lag far behind their advanced European counterparts in terms of introducing technical innovations. However, the urban elite and the city authorities of provincial cities had to overcome considerably more difficulties for their introduction, the degree of their distribution was limited for objective reasons (not only material, but also mental peculiarities of provincial inhabitants)
\end{abstract}

Keywords: cultural landscape, cities, province, diffusion of innovations, electricity.

\section{References}

1. Alekseyev V.V. Elektrifikatsiya Sibiri. Istoricheskoye issledovaniye[Electrification of Siberia. Historical research]. Chast' I. 1885-1950. — Novosibirsk: Nauka, 1973

2. Alekseyeva Ye.V. Yevropeyskaya kul'tura v imperskoy Rossii[European culture in imperial Russia. Penetration, diffusion, synthesis]. Yekaterinburg, 2006. S.138-174.

3. Berdnikov N.N. Gorod v dvukh izmereniyakh [The city in two dimensions]. Sverdlovsk: Sredne — Ural'skoye knizhnoye izdatel'stvo, 1979.

4. GAPO [State archives of Perm region]. F. 35. Op.1. D. 130. L. $14 \mathrm{ob} .-15 \mathrm{ob}$

5. Gramolin A.I., Koridorov E.A. Yekaterinburg - Sverdlovsk - Yekaterinburg. Istoriya gorodskoy vlasti (1745-1919). Dokumental'no-publitsisticheskiye ocherki. [Yekaterinburg - Sverdlovsk - Yekaterinburg. History of city government (1745 1919). Documentary and journalistic essays]. Yekaterinburg, 2003. S.163. 1998

6. Yekaterinburg. Istoricheskiye ocherki (1723-1998). [Yekaterinburg. Historical essays (1723-1998)]. Yekaterinburg,

7. Yerykalina A.Yu. Kul'turnaya zhizn' gorodskogo naseleniya Yuzhnogo Urala (konets KHIKH v. — 1914 g.). [The cultural life of the urban population of the Southern Urals (the end of the nineteenth century - 1914)]. Diss. ...kand. ist. nauk. Chelyabinsk, 2015.

8. Ignat'yev A.A. Pyat'desyat let v stroyu. [Fifty years in the ranks]. 2-kh t. - M.: Pravda, 1989. — T. 1. Kn. $1-3$.

9. Iz istorii feodalizma i kapitalizma v Bashkirii. [From the history of feudalism and capitalism in Bashkortostan]. Ufa, 1971.

10. Kaganskiy V. Rossiya. Provintsiya. Landshaft [Russia. Provinces. Landscape] // Otechestvennyye zapiski. 2006. № 5.

11. Kibardin V.V. Istoriya stroitel'stva pervykh elektricheskikh stantsiy g. Krasnoyarska [History of construction of the first power plants in Krasnoyarsk] // Vestnik Krasnoyarskogo gosudarstvennogo agrarnogo universiteta. № 6. 2011.

12. Koshman L.V. Khudozhestvennaya kul'tura «Serebryanogo veka» [Art culture of the "Silver Age"] // Rossiya v nachale XX v. M., 2002. 


\section{Исторические науки}

13. Kudryavtsev V. Starina, pamyatniki, predaniya i legendy Prikamskogo kraya [Antiquity, monuments, stories and legends of Primorsky Krai] // Pamyatnaya knizhka i kalendar' Vyatskoy gubernii na 1899 god. Vyatka, 1898.

14. Luzin G.A. Opisaniye dvigateley vnutrennego sgoraniya na nekotorykh zavodakh Urala, s kratkim ocherkom razvitiya, deystviya i naznacheniya etikh mashin (izvlecheniye iz otcheta po komandirovke) [Description of internal combustion engines in some factories in the Urals, with a brief outline of the development, operation and purpose of these machines (extraction from the mission report)] // Gornyy zhurnal. 1913. № 1-2.

15. Mil'china V.A. Parizh v 1812 -1848 godakh: povsednevnaya zhizn'. [Paris in 1812 -1848: the daily life]. M.: Novoye literaturnoye obozreniye, 2013. S. 316.

16. Mikityuk, V. P. Povsednevnaya zhizn Ekaterinburga na rubezhe XIX-XX vekov. Ocherki gorodskogo byita / V. P. Mikityuk, O. N. Yahno. — Ekaterinburg : AMB , 2014. — 488 s.

17. Muzey gorodskogo osveshcheniya "Ogni Moskvy". [Museum of the city's lighting "Lights of Moscow".]. http://testan. narod.ru/museum/ogny.htm

18. Muzey istorii energetiki Severo-Zapada. [Museum of the history of electrical power in the North-West]. http://www. energomuseum.ru/timeline/nachalo-ehry-ehlektrichestva/

19. Otstavnova I.V. Prostranstvo rossiyskoy provintsii: "Zhiznesmysly" [The space of the Russian province: "Life meanings"] : diss. ... kand. kul't. Saransk, 2006. 150 c.

20. Otchet Yekaterinburgskoy gorodskoy upravy o dvizhenii summ, kapitalov i imushchestva g. Yekaterinburga za 1901 god. [Report of the Yekaterinburg City Council on the movement of the amounts, capital and property of Yekaterinburg in 1901]. Yekaterinburg, 1903.

21. Otchet po komandirovke gornogo inzhenera M.M. Fedorova. Ocherk sostoyaniya elektricheskikh sooruzheniy na ural'skikh zavodakh i rudnikakh v $1906 \mathrm{~g}$. [Report on the trip of the mining engineer M.M. Fedorov. An outline of the state of electrical facilities at the Ural plants and mines in 1906] // Gornyy zhurnal. 1910. T. IV. № 12.

22. Po voprosu ob ustroystve tramvaya v Yekaterinburge [On the issue of the construction of a tram in Yekaterinburg] // Ural'skiy kray. 1909. № 12.

23. Poznyak T.Z. Zhil'ye i byt gorozhan na dal'nevostochnoy okraine (vtoraya polovina XIX — nachalo XX v.) [Housing and life of citizens in the Far Eastern outskirts (second half of the XIX - early XX century)] // Izvestiya Altayskogo gosudarstvennogo universiteta. № 4-1. 2008.

24. Po Kame i Uralu: putevyye zapiski XIX — nachala XX vv. [On the Kama and the Urals: travelogues of the XIX — early XX centuries.]. Perm', 2011. S.244

25. Prilozheniye k Vyatskim Gubernskim Vedomostyam. Gazeta obshchestvennaya i literaturnaya. [Appendix to the Vyatka Provincial Gazette. The public and literary newspaper]. 6 iyulya 1899 g. № 78.

26. Prilozheniye k Vyatskim Gubernskim Vedomostyam. Gazeta obshchestvennaya i literaturnaya. [Appendix to the Vyatka Provincial Gazette. The public and literary newspaper]. 1902. 24 avgusta. № 101.

27. Prilozheniye k Vyatskim Gubernskim Vedomostyam. Gazeta obshchestvennaya i literaturnaya. [Appendix to the Vyatka Provincial Gazette. The public and literary newspaper]. 19 noyabrya 1902 g. № 138.

28. Prilozheniye k Vyatskim Gubernskim Vedomostyam. Gazeta obshchestvennaya i literaturnaya. [Appendix to the Vyatka Provincial Gazette. The public and literary newspaper]. 1903. 24 iyunya. № 73. S.4.

29. Prilozheniye k Vyatskim Gubernskim Vedomostyam. Gazeta obshchestvennaya i literaturnaya. 1903. 12 avgusta. № 94. S.2.

30. Proyekt elektricheskogo tramvaya [Electric Tram Project] // Zaural'skiy kray. 1913. 14 fevralya. № 37.

31. Rossiya v nachale XX v. [Russia in the beginning of the XX century]. M., 2002.

32. Smyshlyayev D. Sbornik statey o Permskoy gubernii. [Collection of articles on the Perm province]. Perm', 1891.

33. Tramvay v Yekaterinburge [Tram in Yekaterinburg] // Ural'skiy kray. 1909. № 10. S. 2.

34. Trapeznikov V.N. Letopis' goroda Permi. [Chronicle of the city of Perm.]. Perm', 1998. S. 140.

35. Tsyganova YA.M. Rossiyskaya provintsiya poreformennoy epokhi kak istoriko-kul'turnoye prostranstvo: podkhody k izucheniyu [The Russian province of the post-reform era as a historical and cultural space: approaches to studying] // Vestnik SamGU. 2013. № 8/2 (109). S.78.

36. Chesnokova A.N. Inostrantsy i ikh potomki v Peterburge: Nemtsy. Frantsuzy. Britantsy (1703-1917). [Foreigners and their descendants in St. Petersburg: Germans. The French. The British (1703-1917)]. SPb.: SATIS, 2003.

37. Ackroyd P. London. The concise biography. London: Vintage Books, 2012.

38. La Nature. Revue des Sciences. 1885. Treizième année, premier semester. n. 601 à 626. P. 94. URL: http://cnum.cnam. fr/CGI/fpage.cgi?4KY28.24/3/100/432/8/420 (Дата обращения: 4.02. 2017).

39. Une nouvelle lumière électrique à Londres // La Nature. Revue des Sciences. 1873. Première année: n. 1 à 26. P. 158. URL: http://cnum.cnam.fr/CGI/fpage.cgi?4KY28.24/3/100/432/8/420 (Дата обращения: 4.02. 2017).

Received May 22, 2017 